\title{
Effect of Sources and Levels of Phosphorus on Growth and Yield of No-Till Sorghum in Rice-Sorghum Sequence
}

\author{
H. Arunakumari ${ }^{*}$, M. Martin Luther ${ }^{1}$, K. Chandrasekhar ${ }^{2}$, \\ P. Ravindra Babu ${ }^{1}$ and Y. Ashoka Rani ${ }^{1}$
}
${ }^{1}$ Department of Agronomy, Agricultural College, Bapatla, ANGRAU, Andhra Pradesh, India
${ }^{2}$ Department of Agronomy (Water Management) Advanced PG Centre, Lam, Guntur, ANGRAU, Andhra Pradesh, India

*Corresponding author

\begin{tabular}{|c|c|}
\hline & A B S T R A C T \\
\hline $\begin{array}{l}\text { K e y w o r d s } \\
\begin{array}{l}\text { Rice, No-till sorghum, } \\
\text { Phosphorus source, Levels } \\
\text { of phosphorus, Yield }\end{array}\end{array}$ & \multirow{3}{*}{$\begin{array}{l}\text { An investigation was carried out in no-till sorghum to assess the direct and residual effect } \\
\text { of phosphorus management of sorghum in rice-sorghum sequence during rabi, 2016-17 } \\
\text { and 2017-18 on clay loam soils of Agricultural College Farm, Bapatla. All treatments are } \\
\text { randomly allocated in three replications in a split plot design for kharif season and split- } \\
\text { split plot design for rabi season in both the years of study. The most popular sorghum } \\
\text { hybrid CSH-16 was used for experimental purpose. Results showed that a significant } \\
\text { increase in plant height, drymatter accumulation, yield attributes and grain yield of } \\
\text { sorghum were observed with green manuring insitu with dhaincha + PSB applied to rice } \\
\text { on succeeding no-till sorghum and } 50 \% \text { RDP given to sorghum. There was no significant } \\
\text { difference was observed on growth and yield parameters of sorghum where } 50 \% \text { RDP } \\
\text { given to rice on sorghum. }\end{array}$} \\
\hline Article Info & \\
\hline $\begin{array}{l}\text { Accepted: } \\
\text { 04 October } 2018 \\
\text { Available Online: } \\
\text { 10 November } 2018\end{array}$ & \\
\hline
\end{tabular}

\section{Introduction}

Rice - pulse sequence was a dominant cropping sequence in Krishna agro-climatic zone of Andhra Pradesh. The area under this sequence has declined due to late planting of rice in consequence of delay in onset of monsoon and severe incidence of yellow mosaic virus on pulse crop (Mishra et al., 2013). In the changed scenario, farmers are now growing sorghum in rice-fallows as an alternative to pulses.

Phosphorus is an essential, irreplaceable element in all living cells and without it, there would be no living thing on the earth. The importance of phosphorus to life has focused attention on the efficient use of phosphorus in agriculture in recent years for three reasons: 1) Phosphate rock from which phosphate fertilizers are made is a finite, non-renewable resource and it must be used efficiently to maximize its life span. 2) There is a need to maintain and improve the $\mathrm{P}$ status of many soils, particularly those in the least developed countries, for the growth of crops for food, fibre and bio energy. 3) A major determinant of the adverse effect of eutrophication in surface water bodies and can be transferred from soil to water. Phosphorus has become a 
major constraint to agricultural production in India because of scarce natural deposits, steep hike in price of phosphatic fertilizers due to energy crisis throughout the world and also a major portion of raw materials for phosphatic fertilizers has to be imported from foreign countries. By considering all the above factors incorporation of green manures and use of biofertilizers like phosphorus solubilizing bacteria (PSB) will increase the availability of both native and added phosphorus results in overall plant growth and higher productivity instead of going for higher level of phosphatic fertilizers.

\section{Materials and Methods}

The experiment was laid out in a split- split plot design with 12 treatments in kharif and 36 treatments in rabi with three replications. The main plot includes sources of phosphorus viz., inorganic fertilizer phosphorus through SSP, green manuring in-situ with dhaincha @ $25 \mathrm{~kg}$ $\mathrm{ha}^{-1}$, phosphorus solubilizing bacteria biofertilizer @ $0750 \mathrm{ml} \mathrm{ha}{ }^{-1}$ and green manuring in-situ with dhaincha@ $25 \mathrm{~kg} \mathrm{ha}^{-1}+$ phosphorus solubilizing bacteria biofertilizer @ $750 \mathrm{ml} \mathrm{ha}^{-1}$ and levels of phosphorus viz., $50 \%, 100 \%$ and $150 \%$ RDP were allotted to sub plots during kharif season.

The sub plots were again sub divided into three sub-sub plots after rice which includes phosphorus levels viz., control (no phosphorus), $50 \%$ and $100 \%$ RDP in no-till sorghum during 2016-17. The experiment was repeated in another field during kharif and rabi seasons of 2017-18. Green manuring crop of dhaincha at 45 DAS was incorporated fifteen days prior to transplanting of rice in the respective treatments during both the years of study. The experimental soil was clay loam in texture, slightly alkaline in reaction and low in organic carbon, low in available nitrogen, medium in available phosphorus and high in potassium.

\section{Results and Discussion}

Plant height of sorghum was significantly influenced by residual effect of different sources of phosphorus applied to preceding rice and levels of phosphorus applied to sorghum but not by the levels of phosphorus applied to rice. The interaction among the sources and levels of phosphorus were found to be non-significant during both the years of study and also in pooled data. At 30 days after sowing, maximum plant height of sorghum was observed in green manuring along with PSB application which was on a par with green manuring alone and significantly superior to rest of the treatments. The lowest plant height of sorghum was observed with the application of inorganic phosphorus through SSP only during 2016-17 and 2017-18 (Table $1)$.

A significant effect of increased phosphorus levels applied to sorghum was observed on plant height of sorghum. At 30 days, the highest plant height of sorghum $(66.1 \mathrm{~cm}, 67.7$ and 66.9) was observed with $100 \%$ RDP which was comparable with $50 \%$ RDP and significantly superior to that of control (no phosphorus) during 2016-17, 2017-18 and in pooled data. Similar trend was observed at 60, 90 days after sowing and at harvest during both the years of study and in pooled data. Increased plant height was recorded at higher levels of phosphorus application with biological treatments resulted in the availability of higher energy in the form of ATP molecules which would have helped in cell elongation in turn resulted in taller plants. The increase in plant height in response to higher levels of phosphorus was in conformity with the findings of Ashiono et al., (2005) and Pratyusha (2014).

Drymatter accumulation was significantly affected only by residual effect of phosphorus sources given to preceding rice but not by the 
levels. None of the interactions were found significant during both the years of study and in pooled data. Higher amount of drymatter accumulation in no till sorghum was registered with green manuring + PSB given to preceding rice and found significantly superior than other sources of $\mathrm{P}$ applied to rice; however, and it was at par with the green manuring alone.

The lowest drymatter of sorghum was produced by application of inorganic phosphorus through SSP. Similar results were observed at 60 DAS, 90 DAS and at maturity in both the years of study (Table 2 and Fig. 1).

Maximum amount of drymatter accumulation in sorghum was observed with $150 \%$ RDP; whereas the lowest was recorded with $50 \%$ RDP at all stages of crop growth. However, the difference among the levels of phosphorus applied to rice was found to be nonsignificant.

Phosphorus application had significant influence on accumulation of drymatter up to the highest level i.e., $100 \%$ RDP given to sorghum which was comparable with $50 \%$ RDP and significantly superior over control. Similar trend was observed during both the years of study. At maturity the per cent increase in drymatter with 50 and $100 \%$ RDP over control was $8.4 \%$ and $8.6 \%$ during the first year, $7.6 \%$ and $8.4 \%$ during the second year and $8.0 \%$ and $8.5 \%$ in pooled data, respectively indicating linear response to phosphorus application irrespective of different sources of phosphorus. An adequate supply of phosphorus is associated with the enhancement of leaf area index which in turn put forth more photosynthetic surface, thus contributing to more drymatter production. The present results are in close conformity with the previous findings of Ramanjaneyulu (2006), Sareen and Sharma (2010), Gupta et al., (2015) and Kishore et al., (2017).
Data pertaining to number of grains per earhead was presented in Table 3 and reveals that the number of grains per earhead in sorghum was significantly influenced by source of phosphorus given to rice and levels of phosphorus given to sorghum but not by the levels of phosphorus given to preceding rice.

The interaction among main plot, sub plot and sub-sub plot treatments was non-significant during both the years of experiment and also in pooled data.

Among the source of phosphorus given to preceding rice, green manuring + PSB recorded significantly higher number of grains earhead ${ }^{-1}$ in sorghum which was statistically on a par with green manuring alone and significantly superior over other sources of phosphorus.

The number of grains earhead ${ }^{-1}$ observed with the application of SSP alone was significantly lower compared other sources of phosphorus during both the years of study and in pooled data. Number of grains earhead ${ }^{-1}$ in sorghum was not significantly influenced by the phosphorus levels given to preceding rice.

However, the maximum number of grains earhead $^{-1}$ in sorghum was noticed with $150 \%$ RDP which was at par with 50 and $100 \%$ RDP.

A significant increase in number of grains earhead $^{-1}$ was observed due to increase in the levels of phosphorus applied to sorghum from $0 \%$ RDP to $100 \%$ RDP. Application of 100 $\%$ RDP resulted in significantly higher number of grains earhead ${ }^{-1}(2585,2667$ and 2626) over control (2350, 2429 and 2389) and was found on a par with the $50 \% \operatorname{RDP}(2562$, 2636 and 2598) during first year, second year and in pooled data, respectively. These results are in line with the findings of Pushpendra Singh et al., (2012) and Gupta et al., (2015). 
Table.1 Plant height $(\mathrm{cm})$ of sorghum at different stages of crop growth as influenced by phosphorus management in rice- sorghum sequence during rabi 2016-17, 2017-18 and pooled data

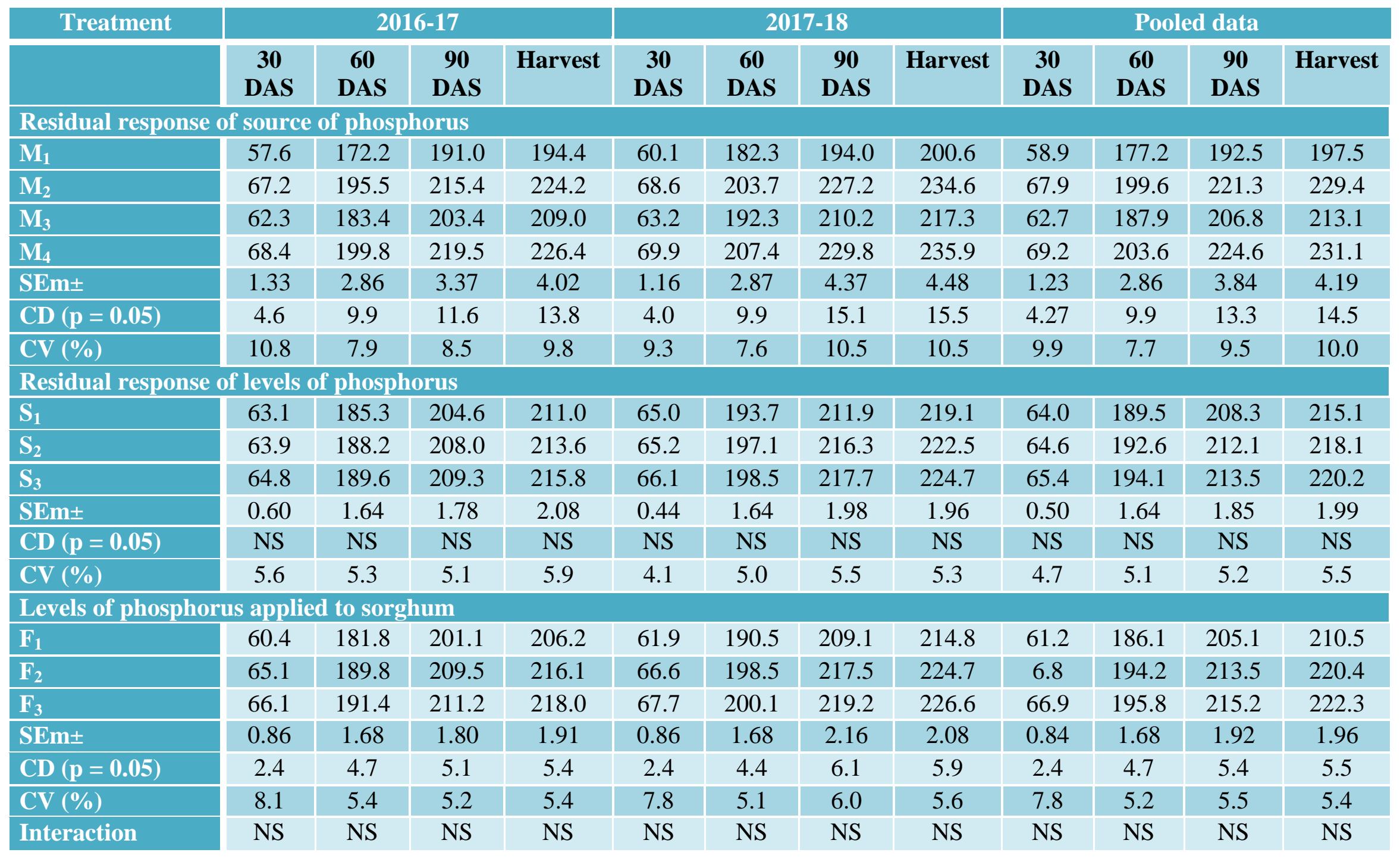


Table.2 Drymatter accumulation $\left(\mathrm{kg} \mathrm{ha}^{-1}\right)$ of sorghum at different stages of crop growth as influenced by phosphorus management in rice-sorghum sequence during rabi 2016-17, 2017-18 and pooled data

\begin{tabular}{|c|c|c|c|c|c|c|c|c|c|c|c|c|}
\hline \multirow[t]{2}{*}{ Treatment } & \multicolumn{4}{|c|}{$2016-17$} & \multicolumn{4}{|c|}{ 2017-18 } & \multicolumn{4}{|c|}{ Pooled data } \\
\hline & $\begin{array}{c}30 \\
\text { DAS }\end{array}$ & $\begin{array}{c}60 \\
\text { DAS }\end{array}$ & $\begin{array}{c}90 \\
\text { DAS }\end{array}$ & Harvest & $\begin{array}{c}30 \\
\text { DAS }\end{array}$ & $\begin{array}{c}60 \\
\text { DAS }\end{array}$ & $\begin{array}{c}90 \\
\text { DAS }\end{array}$ & Harvest & $\begin{array}{c}30 \\
\text { DAS }\end{array}$ & $\begin{array}{c}60 \\
\text { DAS }\end{array}$ & $\begin{array}{c}90 \\
\text { DAS }\end{array}$ & Harvest \\
\hline \multicolumn{13}{|c|}{ Residual response of source of phosphorus } \\
\hline $\mathbf{M}_{1}$ & 1707 & 7497 & 11819 & 14016 & 1827 & 7597 & 12433 & 14263 & 1767 & 7547 & 12126 & 14140 \\
\hline $\mathbf{M}_{2}$ & 1986 & 9008 & 13598 & 15903 & 2062 & 9310 & 13999 & 16060 & 2024 & 9159 & 13798 & 15981 \\
\hline $\mathbf{M}_{3}$ & 1848 & 8315 & 12891 & 14956 & 1940 & 8511 & 13261 & 15229 & 1894 & 8413 & 13076 & 15092 \\
\hline $\mathbf{M}_{4}$ & 2006 & 9152 & 13749 & 16118 & 2068 & 9504 & 14169 & 16264 & 2037 & 9328 & 13960 & 16191 \\
\hline SEm \pm & 38.7 & 104.4 & 171.8 & 269.2 & 31.0 & 95.7 & 181.7 & 240.5 & 34.7 & 98.9 & 174.1 & 253.4 \\
\hline$C D(p=0.05)$ & 134 & 361 & 595 & 932 & 107 & 331 & 629 & 832 & 120 & 342 & 603 & 877 \\
\hline CV (\%) & 10.7 & 6.4 & 6.9 & 9.2 & 8.2 & 5.7 & 7.0 & 8.1 & 9.4 & 6.0 & 6.8 & 8.6 \\
\hline \multicolumn{13}{|c|}{ Residual response levels of phosphorus } \\
\hline $\mathbf{S}_{1}$ & 1873 & 8362 & 12861 & 14976 & 1944 & 8594 & 13309 & 15182 & 1909 & 8478 & 13085 & 15079 \\
\hline $\mathbf{S}_{2}$ & 1877 & 8542 & 13074 & 15366 & 1974 & 8782 & 13527 & 15572 & 1925 & 8662 & 13301 & 15469 \\
\hline $\mathbf{S}_{\mathbf{3}}$ & 1910 & 8575 & 13107 & 15402 & 2005 & 8815 & 13560 & 15608 & 1958 & 8695 & 13334 & 15505 \\
\hline SEm \pm & 23.6 & 77.1 & 107.7 & 178.0 & 25.7 & 83.9 & 90.4 & 148.5 & 24.3 & 79.4 & 94.5 & 161.0 \\
\hline$C D(p=0.05)$ & NS & NS & NS & NS & NS & NS & NS & NS & NS & NS & NS & NS \\
\hline CV $(\%)$ & 7.5 & 5.4 & 5.0 & 7.0 & 7.8 & 5.8 & 4.0 & 5.8 & 7.6 & 5.5 & 4.3 & 6.3 \\
\hline \multicolumn{13}{|c|}{ Levels of phosphorus applied to sorghum } \\
\hline $\mathbf{F}_{1}$ & 1832 & 7790 & 12126 & 14360 & 1919 & 8028 & 12611 & 14603 & 1875 & 7909 & 12369 & 14481 \\
\hline $\mathbf{F}_{2}$ & 1904 & 8835 & 13449 & 15680 & 1993 & 9072 & 13833 & 15812 & 1949 & 8953 & 13641 & 15746 \\
\hline $\mathbf{F}_{3}$ & 1924 & 8854 & 13468 & 15704 & 2012 & 9091 & 13952 & 15947 & 1968 & 8973 & 13710 & 15826 \\
\hline SEm \pm & 19.0 & 111.6 & 150.9 & 156.2 & 18.8 & 116.0 & 142.4 & 144.0 & 18.8 & 113.0 & 142.4 & 146.9 \\
\hline$C D(p=0.05)$ & 54 & 317 & 429 & 444 & 54 & 330 & 405 & 410 & 54 & 321 & 405 & 418 \\
\hline CV $(\%)$ & 6.1 & 7.9 & 7.0 & 6.1 & 5.7 & 8.0 & $6 . .3$ & 5.6 & 5.9 & 7.9 & 6.5 & 5.7 \\
\hline Interaction & NS & NS & NS & NS & NS & NS & NS & NS & NS & NS & NS & NS \\
\hline
\end{tabular}


Table.3 Number of grains earhead ${ }^{-1}$ and test weight $(\mathrm{g})$ of sorghum as influenced by phosphorus management in rice-sorghum sequence during rabi 2016-17, 2017-18 and pooled data

\begin{tabular}{|c|c|c|c|c|c|c|}
\hline \multirow[t]{2}{*}{ Treatment } & \multicolumn{3}{|c|}{ Number of grains earhead $^{-1}$} & \multicolumn{3}{|c|}{ Test weight (g) } \\
\hline & 2016-17 & 2017-18 & Pooled data & 2016-17 & 2017-18 & Pooled data \\
\hline \multicolumn{7}{|c|}{ Residual response of source of phosphorus } \\
\hline $\mathrm{M}_{1^{-}}$Phosphorus through SSP & 1933 & 2054 & 1994 & 24.9 & 25.0 & 24.9 \\
\hline $\mathrm{M}_{2-}$ Green manuring & 2792 & 2807 & 2800 & 25.2 & 25.4 & 25.3 \\
\hline $\mathbf{M}_{3}$ - Soil application of PSB & 2434 & 2568 & 2501 & 25.1 & 25.3 & 25.2 \\
\hline $\mathrm{M}_{4^{-}}$Green manuring + PSB & 2836 & 2876 & 2856 & 25.3 & 25.7 & 25.5 \\
\hline SEm \pm & 59.9 & 56.6 & 58.2 & 0.18 & 0.17 & 0.13 \\
\hline $\mathrm{CD}(\mathrm{p}=0.05)$ & 207 & 196 & 202 & NS & NS & NS \\
\hline $\mathrm{CV}(\%)$ & 12.5 & 11.4 & 11.9 & 3.7 & 3.4 & 2.7 \\
\hline \multicolumn{7}{|c|}{ Residual response of levels of phosphorus } \\
\hline $\mathrm{S}_{1}-\mathbf{5 0 \%} \mathrm{RDP}$ & 2470 & 2545 & 2507 & 24.9 & 25.1 & 25.0 \\
\hline $\mathrm{S}_{2}-100 \% \mathrm{RDP}$ & 2500 & 2579 & 2540 & 25.3 & 25.2 & 25.3 \\
\hline $\mathrm{S}_{3}-150 \% \mathrm{RDP}$ & 2526 & 2605 & 2566 & 25.3 & 25.6 & 25.5 \\
\hline SEm \pm & 19.5 & 20.1 & 19.7 & 0.19 & 0.19 & 0.16 \\
\hline $\mathrm{CD}(\mathrm{p}=0.05)$ & NS & NS & NS & NS & NS & NS \\
\hline $\mathrm{CV}(\%)$ & 4.6 & 4.7 & 4.6 & 4.6 & 4.4 & 3.7 \\
\hline \multicolumn{7}{|l|}{ Levels of phosphorus applied to sorghum } \\
\hline $\mathrm{F}_{1}-0 \% \mathrm{RDP}$ & 2350 & 2429 & 2389 & 24.9 & 25.2 & 25.1 \\
\hline $\mathrm{F}_{2}-\mathbf{5 0} \% \mathrm{RDP}$ & 2562 & 2636 & 2598 & 25.2 & 25.3 & 25.3 \\
\hline $\mathrm{F}_{3}-100 \% \mathrm{RDP}$ & 2585 & 2667 & 2626 & 25.3 & 25.4 & 25.4 \\
\hline SEm \pm & 20.0 & 20.1 & 20.0 & 0.17 & 0.19 & 0.13 \\
\hline $\mathrm{CD}(p=0.05)$ & 57 & 58 & 57 & NS & NS & NS \\
\hline CV $(\%)$ & 4.8 & 4.7 & 4.7 & 4.0 & 4.6 & 3.2 \\
\hline Interaction & NS & NS & NS & NS & NS & NS \\
\hline
\end{tabular}


Table.4 Grain yield $\left(\mathrm{kg} \mathrm{ha}^{-1}\right)$, stover yield $\left(\mathrm{kg} \mathrm{ha}^{-1}\right)$ and harvest index $(\%)$ of sorghum as influenced by phosphorus management in rice-sorghum sequence during rabi 2016-17, 2017-18 and pooled data

\begin{tabular}{|c|c|c|c|c|c|c|c|c|c|}
\hline \multirow[t]{2}{*}{ Treatment } & \multicolumn{3}{|c|}{$2016-17$} & \multicolumn{3}{|c|}{ 2017-18 } & \multicolumn{3}{|c|}{ Pooled data } \\
\hline & $\begin{array}{c}\text { Grain } \\
\text { yield }\end{array}$ & Stover yield & $\begin{array}{c}\text { Harvest } \\
\text { index }\end{array}$ & Grain yield & $\begin{array}{l}\text { Stover } \\
\text { yield }\end{array}$ & $\begin{array}{l}\text { Harvest } \\
\text { index }\end{array}$ & Grain yield & Stover yield & $\begin{array}{c}\text { Harvest } \\
\text { index }\end{array}$ \\
\hline \multicolumn{10}{|c|}{ Residual response of source of phosphorus } \\
\hline $\mathbf{M}_{1}$ & 4723 & 7985 & 37.0 & 4915 & 8235 & 37.3 & 4819 & 8110 & 37.2 \\
\hline $\mathbf{M}_{2}$ & 5814 & 9619 & 37.6 & 6096 & 9792 & 38.3 & 5955 & 9705 & 38.0 \\
\hline $\mathbf{M}_{3}$ & 5316 & 8850 & 37.5 & 5437 & 9012 & 37.6 & 5377 & 8931 & 37.5 \\
\hline $\mathbf{M}_{4}$ & 5992 & 9760 & 38.1 & 6167 & 9919 & 38.4 & 6080 & 9840 & 38.2 \\
\hline SEm \pm & 93.6 & 93.7 & 0.52 & 122.5 & 92.9 & 0.54 & 100.7 & 93.3 & 0.50 \\
\hline$C D(p=0.05)$ & 324 & 324 & NS & 424 & 322 & NS & 349 & 323 & NS \\
\hline $\mathrm{CV}(\%)$ & 8.9 & 5.4 & 7.2 & 11.3 & 5.2 & 7.4 & 9.4 & 5.3 & 6.9 \\
\hline \multicolumn{10}{|c|}{ Residual response of levels of phosphorus } \\
\hline$S_{1}$ & 5427 & 8994 & 37.6 & 5538 & 9096 & 37.7 & 5483 & 9045 & 37.7 \\
\hline $\mathbf{S}_{2}$ & 5475 & 9081 & 37.6 & 5710 & 9297 & 38.0 & 5593 & 9189 & 37.8 \\
\hline $\mathbf{S}_{3}$ & 5483 & 9086 & 37.7 & 5713 & 9326 & 38.0 & 5598 & 9206 & 37.8 \\
\hline SEm \pm & 65.1 & 138.5 & 0.44 & 80.1 & 138.5 & 0.40 & 65.8 & 138.5 & 0.41 \\
\hline $\mathrm{CD}(\mathrm{p}=0.05)$ & NS & NS & NS & NS & NS & NS & NS & NS & NS \\
\hline CV (\%) & 7.2 & 9.2 & 7.1 & 8.5 & 9.0 & 6.5 & 7.1 & 9.1 & 6.5 \\
\hline \multicolumn{10}{|c|}{ Levels of phosphorus applied to sorghum } \\
\hline$F_{1}$ & 4856 & 8314 & 36.8 & 5041 & 8559 & 37.0 & 4949 & 8437 & 36.9 \\
\hline$F_{2}$ & 5740 & 9399 & 37.8 & 5948 & 9539 & 38.3 & 5844 & 9469 & 38.1 \\
\hline$F_{3}$ & 5788 & 9449 & 38.0 & 5972 & 9619 & 38.3 & 5880 & 9534 & 38.1 \\
\hline SEm \pm & 64.1 & 90.7 & 0.35 & 75.6 & 90.7 & 0.41 & 62.7 & 90.7 & 0.36 \\
\hline $\mathrm{CD}(\mathrm{p}=0.05)$ & 183 & 258 & 1.0 & 215 & 258 & 1.2 & 178 & 258 & 1.0 \\
\hline $\mathrm{CV}(\%)$ & 7.1 & 6.0 & 5.6 & 8.0 & 6.0 & 6.5 & 6.8 & 5.9 & 5.8 \\
\hline Interaction & NS & NS & NS & NS & NS & NS & NS & NS & NS \\
\hline
\end{tabular}


Fig.1 Drymatter accumulation $\left(\mathrm{kg} \mathrm{ha}^{-1}\right)$ of sorghum at maturity as influenced by phosphorus management in rice-sorghum sequence during rabi 2016-17, 2017-18 and pooled data

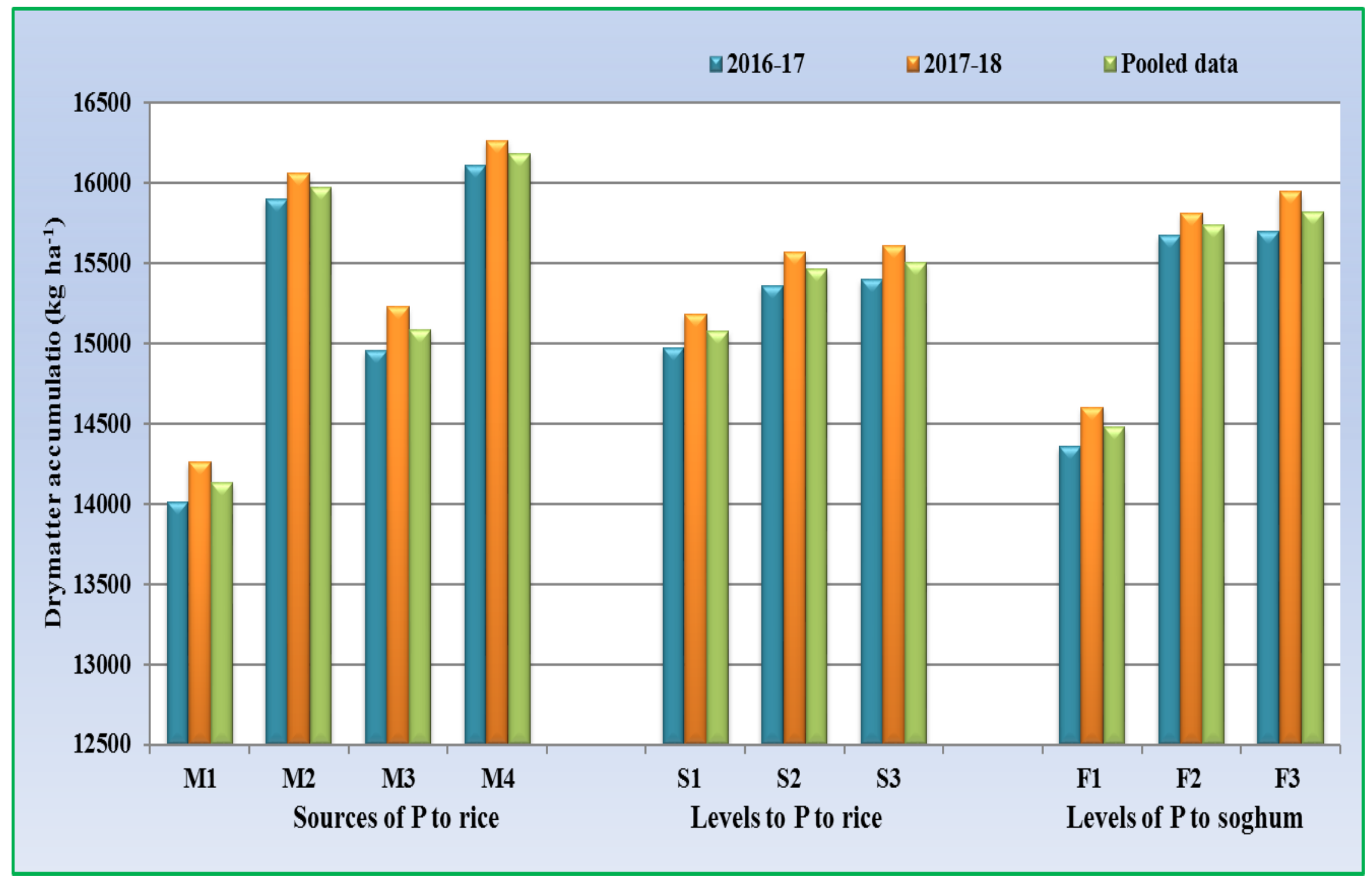


Fig.2 Grain yield $\left(\mathrm{kg} \mathrm{ha}^{-1}\right)$ of sorghum as influenced by phosphorus management in rice-sorghum sequence during rabi 2016-17, 2017-18 and pooled data

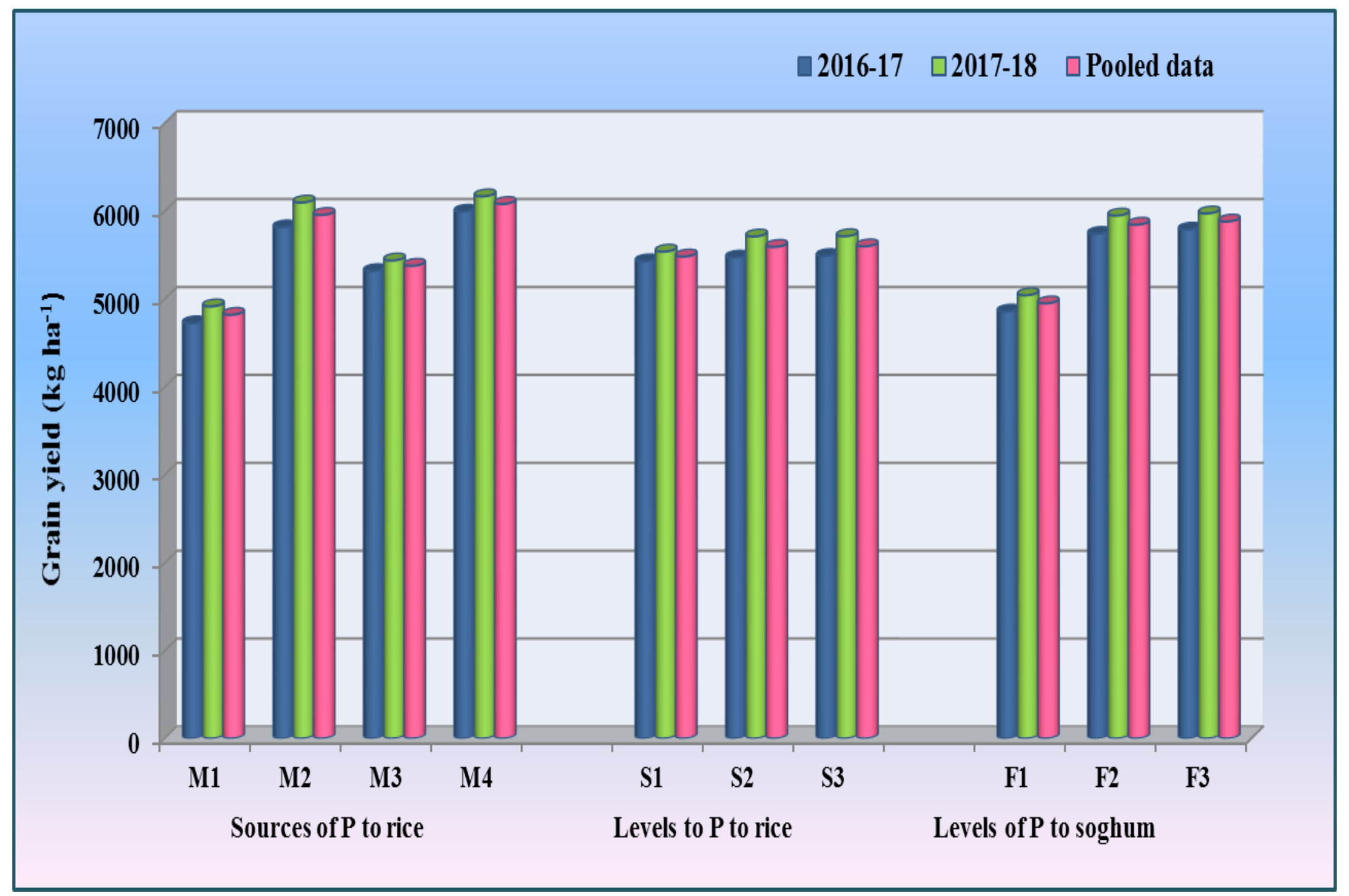


Test weight of sorghum revealed that there was no significant influence on test weight due to sources and levels of phosphorus given to preceding rice and fertility schedule i.e., levels of phosphorus applied to succeeding no till sorghum. The interactions of all these factors were also found to be non-significant during both the years of study and in pooled data.

The grain yield of sorghum was significantly influenced by sources of phosphorus only but not by levels of phosphorus applied to preceding rice during both the years of study. Levels of phosphorus given to succeeding sorghum had significant response on grain yield during both the years of study and in pooled data. There is no significant interaction was found due to different sources and levels of phosphorus applied to preceding rice and levels of phosphorus applied to succeeding no till sorghum.

Grain yield was significantly influenced by different sources of phosphorus imposed to kharif rice crop. The highest grain yield of no till sorghum was recorded due to green manuring + PSB imposed to rice crop during kharif, which was statistically at par with the green manuring alone. A significant decrease in grain yield was recorded with the inorganic phosphorus applied through SSP over other P sources (Table 4 and Fig. 2).

The residual and cumulative beneficial effect of green manuring and PSB on yield attributes was finally reflected in the grain yield during first and second years of study on succeeding no till sorghum crop as it might have promoted the growth of roots as well as functional activity resulting in higher extraction of nutrients from soil environment to aerial plant parts. Application of $150 \%$ RDP resulted in higher grain yield of no till sorghum over rest of the phosphorus levels (50\% and $100 \%$ RDP) and they were at par with each other in the two successive years of study and in pooled data.

With increase in phosphorus level given to no till sorghum, the grain yield increased significantly over no $\mathrm{P}$ application. The highest grain yield was recorded with application of $100 \%$ RDP (5788, 5972 and $5880 \mathrm{~kg} \mathrm{ha}^{-1}$ ) which was at par with the $50 \%$ $\operatorname{RDP}\left(5740,5948\right.$ and $\left.5844 \mathrm{~kg} \mathrm{ha}^{-1}\right)$ and found significantly superior to control (4856, 5041 and $4949 \mathrm{~kg} \mathrm{ha}^{-1}$ ) during the years of 2016$17,2017-18$ and in pooled data respectively.

The per cent increase in grain yield due to 100 $\%$ RDP over $0 \%$ and $50 \%$ RDP was $16.1 \%$ and $0.8 \%$ during first year, $15.6 \%$ and $0.4 \%$ during second year and $15.8 \%$ and $0.6 \%$ in pooled data respectively. Better root growth, enhanced nutrient uptake and translocation of photosynthates from source to sink enhancing the grain yield of sorghum these results corroborate with the findings of Amer and Kewan (2014), Masebo and Menamo (2016) and Sareen et al., (2017).

A significant increase in stover yield of no till sorghum was observed with green manuring + PSB which was statistically at par with green manuring alone, but found to be superior over PSB and inorganic phosphorus through SSP. This was due to continuous and slow release of nutrients which might have increased the leaf area duration, thereby providing an ample time for the plant to increase the photosynthetic rate.

Phosphate solubilizing bacteria are having synergistic effect on plant growth as they increase the phosphorus use efficiency as well as soil fertility by enhancing soil microbial activities. This in turn, could have led to higher drymatter accumulation and resulted in more stover yield. Similar results were obtained by Amanullah et al., (2006) and Altaf Hussain et al., (2012) (Table 4). 
Higher stover yield of succeeding sorghum was observed with increasing level of phosphorus applied in kharif rice but the response was non-significant.

Phosphorus levels given to sorghum had significant influence on stover yield. Application of $100 \%$ RDP resulted in significantly higher stover yield (9449, 9619 and $9534 \mathrm{~kg} \mathrm{ha}^{-1}$ ) which was found at par with $50 \%$ RDP (9399, 9539 and 9469 kg $\mathrm{ha}^{-1}$ ) during $1^{\text {st }}, 2^{\text {nd }}$ year and in pooled data, respectively. This could be ascribed to its positive influence on both vegetative and reproductive growth of the crop which led to increase in stover yield. These findings are in corroboration with the results of Sareen and Sharma (2010), Gupta et al., (2015) and Oprea et al., (2017) (Table 4).

Harvest index of sorghum was not significantly influenced by sources and levels of phosphorus given to rice but levels of phosphorus given to succeeding sorghum had a significant impact during both the years of study and in pooled data.

A significant increase in harvest index was recorded with application of $100 \%$ RDP (38.0, 38.3 and $38.1 \%)$, on a par with that of $50 \% \operatorname{RDP}(37.8,38.3$ and $38.1 \%)$ and found significantly superior over control $(36.8,37.0$ and $36.9 \%$ ) during 2016-17, 2017-18 and in pooled data respectively. The increase in harvest index with increasing phosphorus levels might be due to adequate supply of phosphorus that resulted in enhanced carbohydrate synthesis. Similar results were obtained by Pushpendra Singh et al., (2012) and Sujathamma et al., (2014).

Application of $50 \%$ RDP along with biological sources of phosphorus (green manures, phosphorus solubilizing bacteria) to rice and $50 \%$ RDP to sorghum was found to be optimum with respect to soil health and residual effect on succeeding no till sorghum. This indicated that residual effect of sources and levels of phosphorus can reduce the fertility requirement of rice-sorghum sequence thereby saving of $50 \% \mathrm{RDP}$ in rice and $50 \%$ RDP in sorghum in the ricesequence without compromising yield of both rice and sorghum.

\section{References}

Altaf Hussain, S., Sheraz Mahdi, R.A., Bhat Faisul-ur-Rasool and Raihana Habib Kanth. 2012. Integrated nutrient management of rice (Oryza sativa L.) under temperature conditions of Kasmir. Agric. Sci. Dig. 32 (1): 18-22.

Amanullah, M.M., Alagesan, A., Vaiyapuri, K., Pazhanivelan, S and Sathyamoorthi, K. 2006. Intercropping and organic manures on the growth and yield of cassava (Manihot esculenta crantz). Res. j. agric. biol. sci. 2: 183-189.

Amer, A.I and Kewan, K.Z. 2014. Effect of NP fertilization levels on sorghum (Sorghum bicolor L.) yield and fodder quality for animals. Alex J. Agric. Res. 59 (1): 51-59.

Ashiono, G.B., Gatuiku, S., Mwangi, P and Akuja, T.E. 2005. Effect of nitrogen and phosphorus application on growth and yield of dual purpose sorghum in dry high lands of Kenya. Asian. J. Plant Sci. 4 (4): 379-382.

Gupta, G., Dashora, L.N., Sumeriya, H.K and Dhaker, R.C. 2015. Studies on effect of fertility levels on growth and yield of sorghum (Sorghum bicolor L. Moench) genotypes. Ann. Biol. 31 (2): 201-204.

Kishore, K., Kaushik, M.K., Sharma, N and Yadav, T.K. 2017. Effect of fertility levels on growth and quality of different sorghum (Sorghum bicolor L. Moench) genotypes. Ann. Biol. 33 (2): 247-250.

Masebo, N and Menamo, M. 2016. The effect of application of different rate of N-P 
fertilizers rate on yield and yield components of sorghum (Sorghum bicolor L. Moench): case of derashe woreda, SNNPR, Ethiopia. J. of Nat. Sci. Res. 6: 5.

Mishra, J.S., Chapke, R.R., Subbarayudu, B., Hariprasanna, K and Patil, J.V. 2013. Response of sorghum (Sorghum bicolor L. Moench) hybrids to nitrogen under zero tillage in rice-fallows of coastal Andhra Pradesh. Indian J. of Agric. Sci. 83 (3): 359-361.

Oprea, C.A., Bolohan, C and Marin, D. 2017. Effect of fertilization and row spacing on grain sorghum yield grown in southeastern Romania. Agro Life Scientific J. 6 (1): 173-177.

Pratyusha, Ch. 2014. Response of rice fallow sorghum to crop geometry and phosphorus levels under no-till conditions. M.Sc. (Ag.) thesis, Acharya N. G. Ranga Agricultural University, Hyderabad, India.

Pushpendra Singh, Sumeriya, H. K and Solanki, N. S. 2012. Effect of fertilizer on productivity and economics of elite sorghum genotypes. Madras Agric. J. 99 (7-9): 567-569.

Ramanjaneyulu, A.V., Giri, G and Shivay, Y.S. 2006. Impact of biofertilizers and inorganic nitrogen and phosphorus on fodder yield and nutrient uptake in forage sorghum. ISMN. 47: 49-51.

Sareen, H and Sharma, G.L. 2010. Effect of plant densities and fertilizer levels on growth and NP uptake by extra early sorghum. Ann. of Agric. Res. 31 (1\&2): 32-37.

Sareen, H., Sharma, G.L and Chaplot, P.C. 2017. Effect of plant densities and fertilizer levels on yield attributes and yield of extra early sorghum (Sorghum bicolor L. Moench) genotypes. Ann. of Agri- Bio Res. 22 (2): 185-187.

Sujathamma, P., Kavitha, K and Suneetha, V. 2014. Response of grain sorghum (Sorghum bicolor L.) cultivars to different fertilizer levels under rainfed condition. Int. J. of Agric. Sci. 5 (1): $381-385$.

\section{How to cite this article:}

Arunakumari, H., M. Martin Luther, K. Chandrasekhar, P. Ravindra Babu and Ashoka Rani, Y. 2018. Effect of Sources and Levels of Phosphorus on Growth and Yield of No-Till Sorghum in Rice-Sorghum Sequence. Int.J.Curr.Microbiol.App.Sci. 7(11): 65-76.

doi: https://doi.org/10.20546/ijcmas.2018.711.010 